\title{
SOSIALISASI KEBERADAAN PSDKU UNPAD PANGANDARAN KEPADA SISWA SLTA SE-KAPUPATEN PANGANDARAN
}

\author{
Iwan Sukoco, Dian Fordian, dan Rusdin \\ Administrasi Bisnis, Fakultas Ilmu Sosial dan Ilmu Politik, Universitas Padjadjaran \\ E-mail: iwan.sukoco@unpad.ac.id
}

\begin{abstract}
ABSTRAK. Melalui kerjasama Pemerintah Propinsi Jawa Barat, Pemerintah Kabupaten Pangandaran, dan Universitas Padjadjaran sejak tahun 2016 di Kabupaten Pangandaran berdiri Program Studi Di Luar Kampus Utama (PSDKU) Unpad yang dikenal sebagai Unpad Pangandaran. Berdasarkan penelitian awal dengan melakukan survei kepada 50 orang siswa sekolah lanjutan tingkat akhir (SLTA) di Pangandaran diperoleh data sebagai berikut: 88\% responden mengetahui dan 12\% tidak mengetahui tentang keberadaan PSDKU Unpad Pangandaran. Dari responden yang mengetahui tentang keberadaan PSDKU Unpad Pangandaran, 73\% responden berminat dan 27\% responden menyatakan tidak berminat melanjukan studi ke PSDKU Unpad Pangandaran. Hal tersebut disebabkan, progam studi yang ada di PSDKU Unpad Pangandaran masih relatif sedikit, prosedur pendaftaran masuk belum dipahami dengan baik dan kemampuan ekonomi orang tua yang kurang memadai untuk melanjutkan studi anaknya ke jenjang perguruan tinggi. Atas hal tersebut, kegiatan mahasiwa kuliah kerja nyata (KKN) terintegrasi Pengabdian Kepada Masyarakat (PKM) Unpad di Pangandaran telah mengadakan rangkaian kegiatan sosialisasi keberadaan program studi di luar kawasan utama Unpad kepada siswa SLTA di Kabupaten Pangandaran dalam bentuk talk-show, pameran, dan penyuluhan. Seluruh kegiatan yang telah direncanakan baik program individu maupun bersama dapat dilaksanakan dengan baik. Hal ini didukung oleh antusias peserta yang mengikuti kegiatan tersebut.
\end{abstract}

Kata kunci: sosialisasi; pengabdian masyarakat

ABSTRACT. Through the cooperation of the provincial Government of West Java Regency of Pangandaran, the Government, and Padjadjaran University since the year 2016 in the Regency of Pangandaran stand Courses Outside the main campus (PSDKU) served as known as Unpad Pangandaran. Based on initial research by conducting surveys to students 50 post-graduate school (SLTA) in Pangandaran retrieved data as follows: $88 \%$ of respondents know and $12 \%$ did not know about the existence of PSDKU Unpad Pangandaran. Of the respondents who knew about the existence of PSDKU Unpad Pangandaran, 73\% of respondents are interested and $27 \%$ of respondents stated no mood continues his studies and served as PSDKU to Pangandaran. It caused, the existing studies progam at PSDKU Unpad Pangandaran was still relatively low, the procedure for admission are not yet well understood and the economic capability of the parents who are less adequate for further study of his son to College height. Upon this, the activities of the college students real work (CCN) integrated community services (PKM) and served in Pangandaran had held a series of activities of socialization of the existence of courses outside the main area and served to the students at the SLTA The Regency of Pangandaran in the form of talk-show, exhibition, and outreach. All activities that have been planned for both individual and joint programs can be implemented properly. It is supported by enthusiastic participants who follow the event.

Key words: socialization; community services

\section{PENDAHULUAN}

Kabupaten Pangandaran merupakan daerah otonom baru di Jawa Barat yang secara resmi dimekarkan dari Kabupaten Ciamis pada tahun 2012. Sebagai daerah otonom baru, Pemerintah kabupaten Pangandaran memacu pembangunan di berbagai sektor guna megejar ketertinggalan dari daerah-daerah lain di Jawa Barat. Potensi alam yang dimiliki Pangandaran menjadikan Pangandaran merupakan salah satu obyek wisata andalan. Bahkan Pemerintah Jawa Barat menjadikan Pangandaran sebagai salah satu daerah untuk pengembangan metropolitan dan pusat pertumbuhan di Jawa Barat.

Salah satu masalah dalam pembangunan kabupaten Pangandaran adalah keterbatasan sumber daya manusia dari aparatur pemerintah dan masyarakatnya. Untuk ini pemerintah kabupaten Pangandaran berupaya meningkatan kualitas sumber daya manusianya dengan memacu pembangunan di sektor pendidikan masyarakatnya. Melalui kerjasama Pemerintah Propinsi Jawa Barat, Pemerintah Kabupaten Pangandaran, dan Universitas Padjadjaran sejak tahun 2016 di Pangandaran berdiri Program Studi Di luar Kawasan Utama (PSDKU) Unpad yang dikenal sebagai Unpad Pangandaran.
PSDKU Unpad lebih diprioritaskan bagi masyarakat Kabupaten Pangandaran dan sekitarnya. Berdasarkan tabel 1, jumlah mahasiswa yang ditargetkan tiap semester sebanyak 150 orang yang berarti tiap program studi 30 orang. Namun pada kenyataannya, pada tahun ke dua keberlangsungan PSDKU jumlah mahasiswa secara keseluruhan hanya 187 orang atau sekitar $62 \%$ dari daya tampung mahasiswa PSDKU.

Berdasarkan penelitian awal dengan melakukan survei kepada 50 orang siswa SLTA di Pangandaran diperoleh gambaran sebagai berikut: 44 orang (88\%) responden mengetahui tentang keberadaan PSDKU Unpad Pangandaran, dan 6 orang (12\%) tidak mengetahui tentang keberadaan PSDKU Unpad Pangandaran. Dari 44 orang responden yang mengetahui tentang keberadaan PSDKU Unpad Pangandaran, 32 orang (73\%) responden berminat melanjukan studi ke PSDKU Unpad Pangandaran, dan 12 orang $(27 \%)$ responden menyatakan tidak berminat melanjukan studi ke PSDKU Unpad Pangandaran.

Fenomena masalah yang muncul tersebut di atas diduga karena ada beberapa sebab, diantaranya karena progam studi yang ada di PSDKU Unpad Pangandaran masih relatif sedikit, prosedur pendaftaran masuk 
Tabel 1. Data Mahasiswa PSDKU Unpad Tahun 2016 dan 2017

\begin{tabular}{|c|c|c|c|c|}
\hline \multirow[b]{2}{*}{ NO } & \multirow[b]{2}{*}{ PROGRAM STUDI } & \multicolumn{2}{|c|}{ JUMLAH MAHASIWA } & \multirow[b]{2}{*}{ JUMLAH KESELURUHAN } \\
\hline & & Asal Pangandaran & Bukan Asal Pangandaran & \\
\hline 1 & Administrasi Bisnis & 20 & 14 & 34 \\
\hline 2 & Ilmu Komunikasi & 23 & 14 & 37 \\
\hline 3 & Peternakan & 19 & 19 & 38 \\
\hline 4 & Perikanan dan Ilmu Kelautan & 18 & 30 & 48 \\
\hline 5 & Keperawatan & 19 & 21 & 40 \\
\hline \multicolumn{2}{|c|}{ JUMLAH KESELURUHAN } & 99 & 88 & 187 \\
\hline
\end{tabular}

Sumber : PSDKU Unpad Pangandaran, 2018

PSDKU Unpad Pangandaran yang belum dipahami dengan baik, dan kemampuan ekonomi orang tua yang kurang memadai untuk melanjutkan studi anaknya ke jenjang perguruan tinggi.

Atas dasar latar belakang tersebut, salah satu kegiatan mahasiwa KKN terintegrasi PKM Unpad di Pangandaran berencana mengadakan rangkaian kegiatan sosialisasi keberadaan PSDKU Unpad kepada siswa SLTA di kabupaten Pangandaran.

\section{METODE}

Kegiatan KKN-PKM ini dilakukan di Kampus PSDKU Unpad Pangandaran. Lokasi tersebut dipilih karena kegiatan yang dilakukan merupakan sosialisasi PSDKU Unpad Pangandaran dan sasaran dari kegiatan ini merupakan siswa SMA di Kab. Pangandaran.

Kegiatan pelaksanaan sebagai berikut :

\section{Tahap Persiapan}

- Pembekalan KKN

- Rapat Mahasiswa KKN

- Rapat Koordinasi dengan Mahasiswa PSDKU Unpad Pangandaran dan dengan dosen pembimbing lapangan.

- Pembagian Kuisioner ke siswa SMUN Parigi sebagai studi pendahuluan

2. Tahap pelaksanaan dan Lapangan

- Pembagian Surat Undangan Kepada pemerintah daerah dan siswa SMA di Kab.Pangandaran

- Persiapan untuk sosialisasi

- Pelaksanaan kegiatan : Sosialisasi PSDKU Unpad Pangandaran, Sosialisasi Hoax, Bullying, dan Kesehatan Reproduksi

3. Tahap Pasca Lapangan

- Pembuatan Laporan KKN dan PKM

\section{Mekanisme Kerja Kelompok dalam Pelaksanaan KKN}

Peserta KKNUnpad di kampus Unpad Pangandaran, Kabupaten Pangandaran berjumlah 10 orang. Yang terdiri dari berbagai fakultas, diantaranya Fakultas Hukum (FH), Fakultas Ilmu social dan politik (FISIP), Fakultas Ilmu Budaya (FIB), Fakultas Peternakan (FPET), Fakultas Ilmu Komunikasi (FIK), dan Fakultas Keperaawatan (FKEP). Kegiatan KKN ini dilakukan selama satu bulan yang diawali oleh pembekalan KKN dengan DPL hingga masa persiapan kegiatan di mana mahasiswa menetap di kampus Unpad Pangandaran. Peserta KKN di kampus Unpad Pangandaran di bagi dengan beberapa tugas untuk menjalankan kegiatannya seperti pada gambar 1 . Tugas ini dibagi berdasarkan kebutuhan pada masa pelaksanaan kegiatan, sehingga semua dapat dipersiapkan dengan baik.

\section{HASIL DAN PEMBAHASAN}

\section{Analisis Situasi \\ Kabupaten Pangandaran}

Kabupaten Pangandaran merupakan daerah otonom baru di Jawa Barat yang secara resmi dimekarkan dari Kabupaten Ciamis pada tahun 2012. Undang-undang nomor 21 tahun 2012 mendasari lahirnya kabupaten baru (DOB) yang ditandatangani oleh Presiden Susilo Bambang Yudhoyono pada tanggal 16 November tahun 2012. Kemudian diundangkan oleh Menteri Hukum dan HAM Amir Syamsudin pada tanggal 17 November tahun 2012, maka Pangandaran resmi menjadi Kabupaten di Provinsi Jawa Barat. Dalam UU No. 21/2012 disebutkan, Kabupaten Pangandaran berasal dari sebagian wilayah Kabupaten Ciamis, yang terdiri dari : Kecamatan Parigi, Kecamatan Cijulang, Kecamatan Cimerak, Kecamatan Cigugur, Kecamatan Langkaplancar, Kecamatan Mangunjaya, Kecamatan Padaherang, Kecamatan Kalipucang, Kecamatan Pangandaran dan Kecamatan Sidamulih. Ibu Kota Kabupaten Pangandaran berkedudukan di Kecamatan Parigi.

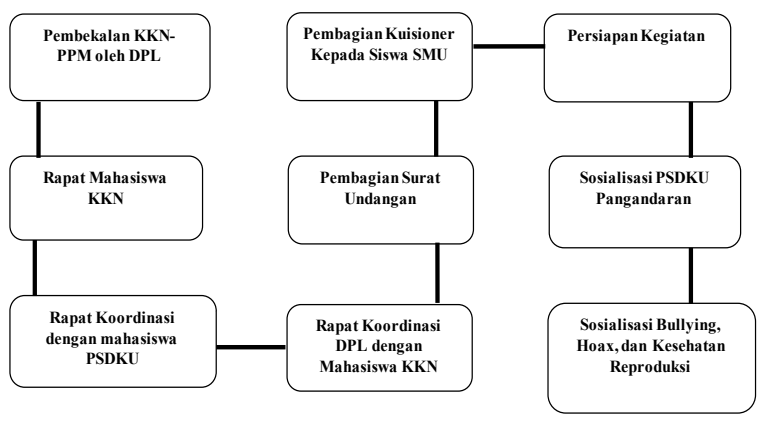

Gambar 1. Alur Tahapan Kegiatan KKN-PKM

Sebagai daerah otonom baru, Pemerintah Kabupaten Pangandaran memacu pembangunan di berbagai sektor guna megejar ketertinggalan dari daerah-daerah lain di Jawa Barat. Potensi alam yang dimiliki Kabupaten Pangandaran menjadikan Kabupaten Pangandaran merupakan salah satu obyek wisata andalan di Jawa Barat. Bahkan Pemerintah Jawa Barat menjadikan Pangandaran sebagai salah satu 
daerah untuk pengembangan metropolitan dan pusat pertumbuhan di Jawa Barat. Dengan potensi yang besar dibidang pariwisata maka misi Kabupaten Pangandaran yaitu "Kabupaten Pangandaran pada tahun 2025 menjadi kabupaten pariwisata yang mendunia, tempat tinggal yang aman dan nyaman berlandaskan norma agama.

Salah satu masalah dalam pembangunan kabupaten Pangandaran adalah keterbatasan sumber daya manusia dari aparatur pemerintah dan masyarakatnya. Untuk ini pemerintahkabupaten Pangandaran berupayameningkatan kualitas sumber daya manusianya dengan memacu pembangunan di sektor pendidikan masyarakatnya.

\section{Eksistensi PSDKU Unpad}

Melalui kerjasama Pemerintah Propinsi Jawa Barat, Pemerintah Kabupaten Pangandaran, dan Universitas Padjadjaran sejak tahun 2016 di Pangandaran berdiri Program Studi Di luar Kawasan Utama (PSDKU) Unpad yang dikenal sebagai Unpad Pangandaran. PSDKU Unpad lebih diprioritaskan bagi masyarakat kabupaten Pangandaran dan sekitarnya. Namun berdasarkan data, tahun pertama PSDKU Unpad menerima mahasiswa sebanyak 92 orang, dari jumlah itu mahasiswa yang berasal dari kabupaten Pangandaran tidak mencapai 50\% nya. Tahun kedua jumlah mahasiswa yang diterima yang berasal dari kabupaten Pangandaran dan sekitarnya masih kurang dari 50\% nya juga. Dengan demikian mahasiswa yang berasal dari kabupaten Pangandaran masih relatif kecil/sedikit.

Berdasarkan observasi lapangan dengan melakukan survei kepada 50 orang siswa SLTA (diambil sampel siswa SMUN Parigi) di Pangandaran diperoleh gambaran sebagai berikut : 44 orang $(88 \%)$ responden mengetahui tentang keberadaan PSDKU Unpad Pangandaran, dan 6 orang (12\%) tidak mengetahui tentang keberadaan PSDKU Unpad Pangandaran. Dari 44 orang responden yang mengetahui tentang keberadaan PSDKU Unpad Pangandaran, 32 orang $(73 \%)$ responden berminat melanjukan studi ke PSDKU Unpad Pangandaran, dan 12 orang $(27 \%)$ responden menyatakan tidak berminat melanjukan studi ke PSDKU Unpad Pangandaran.

Fenomena masalah yang muncul tersebut di atas diduga karena ada beberapa sebab, diantaranya karena progam studi yang ada di PSDKU Unpad Pangandaran masih relatif sedikit, prosedur pendaftaran masuk PSDKU Unpad Pangandaran yang belum dipahami dengan baik, dan kemampuan ekonomi orang tua yang kurang memadai untuk melanjutkan studi anaknya ke jenjang perguruan tinggi.

\section{Program KKN Integrasi PKM Mahasiswa}

Tabel 3. Rapat Koordinasi

\begin{tabular}{ll}
\hline \multicolumn{1}{c}{ Nama Kegiatan } & \multicolumn{1}{c}{ Rapat Koordinasi } \\
\hline Jenis Kegiatan & Rapat \\
& Berkoordinasi dengan mahasiswa \\
& PSDKU untuk menjalin kerja sama \\
Tujuan dan Manfaat & dalam melaksanakan kegiatan \\
& sosialisasi PSDKU kepada siswa \\
& SMA se kabupaten Pangandaran
\end{tabular}

\begin{tabular}{|c|c|}
\hline Sasaran Kegiatan & Mahasiswa PSDKU Pangandaran \\
\hline $\begin{array}{l}\text { Pihak-pihak yang } \\
\text { Terlibat }\end{array}$ & $\begin{array}{l}\text { Himpunan Mahasiswa dan BEM } \\
\text { PSDKU Pangandaran, serta } \\
\text { mahasiswa KKN }\end{array}$ \\
\hline Capaian Kegiatan & $\begin{array}{l}\text { Mendapatkan alur koordinasi } \\
\text { yang baik antara mahasiswa KKN } \\
\text { dengan mahasiswa } \\
\text { PSDKU yang akan terlibat dalam } \\
\text { kegiatan sosialisasi. }\end{array}$ \\
\hline $\begin{array}{l}\text { Rancangan Tindak } \\
\text { Lanjut }\end{array}$ & $\begin{array}{l}\text { Menginformasikan alur koordinasi } \\
\text { kepada dosen. }\end{array}$ \\
\hline
\end{tabular}

Tabel 4. Pembagian Kuisioner

\begin{tabular}{|c|c|}
\hline Nama Kegiatan & Pembagian Kuisioner \\
\hline Jenis Kegiatan & Pengumpulan data \\
\hline Tujuan dan Manfaat & $\begin{array}{l}\text { Mendapatkan data } \\
\text { mengenai pengetahuan } \\
\text { dan minat siswa SMA di } \\
\text { Kab. Pangandaran untuk } \\
\text { melanjutkan studi di } \\
\text { PSDKU Pangandaran. }\end{array}$ \\
\hline Sasaran Kegiatan & Siswa SMA \\
\hline $\begin{array}{l}\text { Pihak-pihak yang } \\
\text { Terlibat }\end{array}$ & Mahasiswa KKN dan Siswa SMU \\
\hline Capaian Kegiatan & $\begin{array}{l}\text { Terkumpulnya data mengenai } \\
\text { jumlah siswa yang mengetahui } \\
\text { PSDKU Pangandaran dan jumlah } \\
\text { sisw yang beminat melanjutkan } \\
\text { pendidikan ke } \\
\text { PSDKU Pangandaran }\end{array}$ \\
\hline $\begin{array}{l}\text { Rancangan Tindak } \\
\text { Lanjut }\end{array}$ & $\begin{array}{l}\text { Pengolahan data dan bahan untuk } \\
\text { materi pembicara }\end{array}$ \\
\hline
\end{tabular}

Tabel 5. Sosialisasi PSDKU

\begin{tabular}{|c|c|}
\hline Nama Kegiatan & Sosialisasi PSDKU Pangandaran \\
\hline Jenis Kegiatan & Talkshow dan Pameran Prodi \\
\hline Tujuan dan Manfaat & $\begin{array}{l}\text { Memberikan informasi kepada siswa } \\
\text { mengenai kampus Unpad PSDKU } \\
\text { Pangandaran, Prodi, jalur masuk, dan } \\
\text { beasiswa. }\end{array}$ \\
\hline Sasaran Kegiatan & Siswa SLTA se- Kab. Pangandaran \\
\hline $\begin{array}{l}\text { Pihak-pihak yang } \\
\text { Terlibat }\end{array}$ & $\begin{array}{l}\text { Himpunan Mahasiswa dan BEM } \\
\text { PSDKU Pangandaran, mahasiwa } \\
\text { KKN, DPL, dan siswa SMA se-Kab. } \\
\text { Pangandaran }\end{array}$ \\
\hline Capaian Kegiatan & $\begin{array}{l}\text { Siswa SLTA lebih memahami mengenai } \\
\text { alur masuk, beasiswa, dan prodi yang } \\
\text { ditawarkan di PSDKU Pangandaran. } \\
\text { Selain itu, mereka pun mendapatkan } \\
\text { pemahaman yang lebih lengkap mengenai } \\
\text { pembelajaran yang akan didapatkan di } \\
\text { prodi yang ditawarkan. }\end{array}$ \\
\hline $\begin{array}{l}\text { Rancangan Tindak } \\
\text { Lanjut }\end{array}$ & $\begin{array}{l}\text { Memberikan gambaran kepada BEM } \\
\text { dan Hima PSDKU yang kemungkinan } \\
\text { dapat menjadi program mahasiswa } \\
\text { kedepannya mengenai promosi PSDKU } \\
\text { Pangandaran. }\end{array}$ \\
\hline
\end{tabular}


Tabel 7. Output Kegiatan/Program KKN-PPM Mahasiswa

\begin{tabular}{|c|c|c|c|}
\hline No & Nama Kegiatan & Sebelum Kegiatan & Setelah Kegiatan \\
\hline 1. & Rapat Koordinasi & $\begin{array}{l}\text { Belum didapatkan gambaran mengenai } \\
\text { alur kerja sama dengan pihak PSDKU } \\
\text { Pangandaran dalam kegiatan sosialisasi } \\
\text { yang akan dilakukan }\end{array}$ & $\begin{array}{l}\text { Didapatkan alur koordinasi yang jelas, } \\
\text { pembagian tugas, dan kejelasan pembukaan } \\
\text { stand untuk memperkenalkan setiap jurusan } \\
\text { di PSDKU Pangandaran. }\end{array}$ \\
\hline 2. & Pembagian Kuisioner & $\begin{array}{l}\text { Tidak adanya data yang menjelaskan } \\
\text { mengenai belum tercapainya target } \\
\text { PSDKU Pangandaran dalam } \\
\text { menjaring siswa yang berasal dari } \\
\text { Pangandaran }\end{array}$ & $\begin{array}{l}\text { Diketahui beberapa alasan mengapa siswa } \\
\text { tidak berminat melanjutkan studi ke PSDKU } \\
\text { Pangandaran dan juga informasi mengenai } \\
\text { PSDKU Pangandaran. }\end{array}$ \\
\hline 3. & $\begin{array}{l}\text { Sosialisasi } \\
\text { PSDKUpangandaran }\end{array}$ & $\begin{array}{l}\text { Siswa masih bingung mengenai prodi, } \\
\text { jalur masuk, dan penawaran beasiswa di } \\
\text { PSDKU Pangandaran }\end{array}$ & $\begin{array}{l}\text { Siswa lebih memahami mengani beberapa } \\
\text { hal tentang PSDKU Pangandaran terutama } \\
\text { masalah jalur masuk, pembelajaran setiap } \\
\text { prodi, profil lulusan setiap prodi, dan } \\
\text { kesempatan beasiswa yang dimiliki siswa } \\
\text { setelah enjadi mahasiswa di kampus } \\
\text { PSDKU Pangandaran. }\end{array}$ \\
\hline 4. & $\begin{array}{l}\text { Sosialisasi Bullying, Hoax, } \\
\text { dan Kesehatan Reproduksi }\end{array}$ & $\begin{array}{l}\text { Siswa telah mengetahui mengenai hal-hal } \\
\text { yang disosialisasikan, namun tidak secara } \\
\text { menyeluruh. }\end{array}$ & $\begin{array}{l}\text { Siswa menjadi paham mengenai hal-hal } \\
\text { tersebut. }\end{array}$ \\
\hline
\end{tabular}

Tabel 6. Sosialisasi Bullying, Hoax, dan Kesehatan Reproduksi

\begin{tabular}{|c|c|}
\hline Nama Kegiatan & $\begin{array}{l}\text { Sosialisasi Bullying, Hoax, dan } \\
\text { Kesehatan Reproduksi }\end{array}$ \\
\hline Jenis Kegiatan & Sosialisasi \\
\hline Tujuan dan Manfaat & $\begin{array}{l}\text { Memberikan informasi terkait } \\
\text { bahaya dan cara menanggulangi } \\
\text { Bullying, Hoax, dan Kesehatan } \\
\text { Reproduksi }\end{array}$ \\
\hline Sasaran Kegiatan & Siswa SLTA \\
\hline $\begin{array}{l}\text { Pihak-pihak yang } \\
\text { Terlibat }\end{array}$ & Mahasiswa KKN dan Siswa SLTA \\
\hline Capaian Kegiatan & $\begin{array}{l}\text { Siswa mengetahui penting } \\
\text { dan bahayanya hoax, bullying, } \\
\text { dan kesehatan reproduksi agar } \\
\text { kedapannya dapa menjadi lebih } \\
\text { aware. }\end{array}$ \\
\hline $\begin{array}{l}\text { Rancangan Tindak } \\
\text { Lanjut }\end{array}$ & $\begin{array}{l}\text { Merekomendasikan hal serupa } \\
\text { untuk dilaksanakan rutin kepada } \\
\text { pihak PSDKU Pangandaran. }\end{array}$ \\
\hline
\end{tabular}

\section{SIMPULAN}

Berdasarkan laporan program kerja yang telah di jelaskan pada bagian sebelumnya, dapat disimpulkan bahwa yang telah direncanakan baik program individu maupun bersama dapat dilaksanakan dengan baik. Hal ini didukung oleh antusias peserta sosialisasi yang mengikuti kegiatan KKN-PKM kami. Dan dilihat dari dukungan serta arahan pembimbing kepada mahasiswa KKN yang sangat membantu dalam menjalankan program kerja atau kegiatan.

Di sisi lain, terdapat beberapa kekurangan yang mengharuskan program kerja atau kegiatan tidak dapat berjalan sesuai dengan jadwal yang telah direncanakan, yaitu miskomunikasi dan minimnya koordinasi dari setiap penanggung jawab program kerja atau kegiatan serta dosen pembimbing KKN. Meskipun demikian pelaksanaan kegiatan tidak merasa begitu kesulitan dalam melaksanakan program kerja atau kegiatan utama, hal ini mengakibatkan ketidaksesuaian perencanaan dan pelaksanaannya.

\section{DAFTAR PUSTAKA}

Dinas Komunikasi; Informatika; Statistik dan Persandian Kabupaten Pangandaran. (t.thn.). Profil Pangandaran. Diambil kembali dari Pangandarankab.go.id:www.pangandarankab. go.id/profil-pangandaran/ 